\title{
RELATIVE LROSIVENESS OF PUERTO RICO SOILS
}

\author{
J. A. BONNET AND M. A. LUGO LÓPEZ*
}

\section{INTRODUCTION}

Middleton (4) proposed the dispersion ratio, a function of soil aggregation, and the colloid-moisture equivalent ratio, a function of the ease of percolation and the absorptive power of a soil, as indices of the susceptibility of a soil to erosion. He further combined these two into a single one, the erosion ratio.

Data obtained from 1939 to 1942 in a cooperative project with the Soil Conservation Service, for soils of Puerto Rico, was used as a basis to calculate those ratios with the objective of evaluating, if possible, the erosiveness of Puerto Rico soils. Very little has been published concerning the degree of erodibility of these soils or of other tropical countries.

\section{LOCATION AND SAMPLING OF SOILS}

Five soil conservation areas, as outlined by the Soil Conservation Service were selected, four in the humid region and one in the semiarid. region of Puerto Rico. These areas are representative of certain definite soil conditions in the Island. In the Río Piedras area in the north, the upland lateritic soils of the Rio Piedras series, and the podzolic soils of the Yunes series (7) both lithosols derived from ashy shales, and the alluvial Coloso soils derived from tuffaceous materials of the adjacent hills, are found. The Mayagüez area in the western section of the Island and the Luquillo area in the northeast are representative of the upland deep lateritic Catalina and Cialitos soils. The area of Castañer in Adjuntas includes the coffee soils of Puerto Rico where such deep lateritic soils as Alonso and Cialitos clay predominate with minor extensions of medium deep soils of the Múcara series. The parent material of the soils in those last three areas consists mostly of massive tuffs and other volcanic rocks. The Lafayette area, in the southeast, includes the upland Cayaguá and alluvial Machete soils derived from quartz diorite.

A total of 64 soil samples were taken, of which 47 were from various depths in 16 profiles of the five Soil Conservation areas; three special samples from a profile of Pandura sandy clay loam, a lithosol derived from quartz diorite, and 14 from four profiles of Catalina clay in run-off plots established by the Soil Conservation Service at Mayagüez.

* Head, Soils Department, and Associate Soil Scientist, respectively, Agricultural Experiment Station, University of Puerto Rico. 


\section{METHODS OF ANALYSES AND CALCULATIONS}

The following determinations were made in soil samples air-dried and passed thru a $2 \mathrm{~mm}$. sieve: $\mathrm{pH}$, bulk density or volume weight, organic matter, colloids and moisture-equivalent. Aggregate analyses were made in moist samples sifted likewise.

The $\mathrm{pH}$ was measured with the potentiometer in a soil-water extract saturated with quinhydrone. Bulk density was determined by the paraffin immersion method, the organic matter by oxidizing with chromic acid, and the moisture-equivalent by using a special centrifuge. The colloids were determined by the pipette method, taking the colloids as the clay fraction below $0.002 \mathrm{~mm}$. Aggregate analyses and total silt and clay were run with a Kopecky type of elutriator (1) consisting of three vessels with internal diameters of 30,56 and $178 \mathrm{~mm}$., respectively. The first vessel retained the particles with a diameter range $2.0-0.1 \mathrm{~mm}$.; the second one with $0.1-0.05$ $\mathrm{mm}$., and the third with $0.05-0.02 \mathrm{~mm}$. An aggregate analysis was run in each sample, and a second one was run after destroying the organic matter with hydrogen peroxide and dispersing the colloids with sodium silicate. The silt and clay aggregated (3), the dispersion, colloid-moisture equivalent and erosion ratios $(4,5,6)$, were calculated as follows:

$$
\begin{gathered}
\text { Dispersion }=\frac{\% \text { silt and clay aggregated }}{\text { total silt and clay }} \times 100 \\
\% \text { silt and clay aggregated }=\frac{x-y}{100-y} \times 100
\end{gathered}
$$

where $x=$ all particles greater than $.05 \mathrm{~mm}$. in the soil in its natural occurrence' without dispersion,

and $y=$ all particles greater than $.05 \mathrm{~mm}$. in the soil after the organic matter is destroyed and the soil dispersed.

total silt and clay $=$ all particles less than $0.05 \mathrm{~mm}$. after dispersion.

$$
\begin{aligned}
& \begin{array}{l}
\text { Colloid moisture } \\
\text { Equivalent ratio }
\end{array}=\frac{\% \text { particles less than } 0.002 \mathrm{~mm}}{\text { moisture equivalent }} \\
& \text { Erosion Ratio }=\frac{\text { Dispersion ratio }}{\text { Colloid-moisture equivalent }}
\end{aligned}
$$

\section{PRESENTATION OF DATA AND DISCUSSION}

The soils were classified into groups: lateritic, red yellow podzolic, gray brown podzolic or lithosols, reddish prairie, and alluvial, and summarized data are reported (table 1) for extreme values of colloids, moisture equivalent, total and aggregated silt and clay, dispersion, colloid-moisture equivalent and erosion ratios of the soil profiles. Detailed data for each soil type are also reported (Appendix, tables 3-8) including also $\mathrm{pH}$, bulk density and organic matter. 


\begin{tabular}{|c|c|c|c|c|c|c|}
\hline 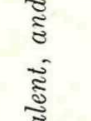 & 产。 & 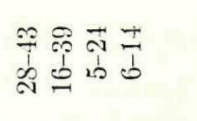 & 节先 & 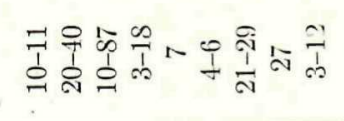 & $\begin{array}{l}E \\
\stackrel{I}{ \pm} \\
E\end{array}$ & $\frac{\overrightarrow{0}}{\frac{1}{1}}$ \\
\hline 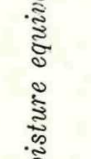 & 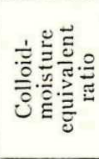 & 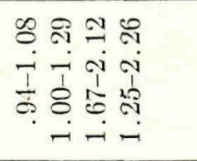 & 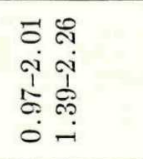 & 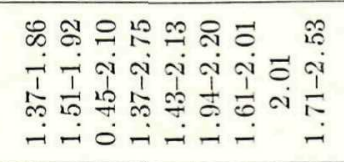 & $\begin{array}{l}0 \\
\stackrel{0}{0} \\
0 \\
1 \\
\frac{1}{0} \\
0\end{array}$ & $\begin{array}{l}12 \\
10 \\
0 \\
1 \\
7 \\
0 \\
0\end{array}$ \\
\hline 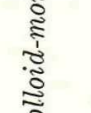 & 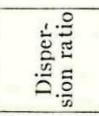 & 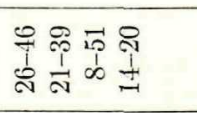 & 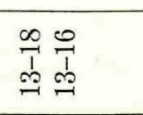 & 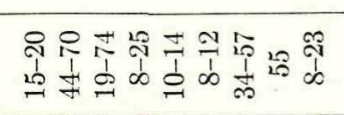 & $\begin{array}{l}5 \\
\infty \\
1 \\
\delta\end{array}$ & $\frac{9}{1}$ \\
\hline 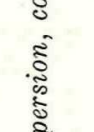 & 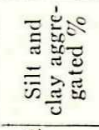 & 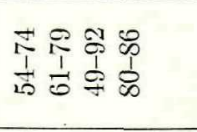 & $\begin{array}{ll}\infty & 1 \\
\infty & \infty \\
1 & \frac{1}{\infty} \\
\infty & \infty\end{array}$ & 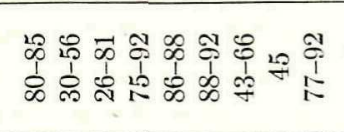 & $\begin{array}{l}\vec{c} \\
1 \\
12\end{array}$ & $\overbrace{i}^{p}$ \\
\hline 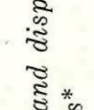 & 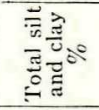 & 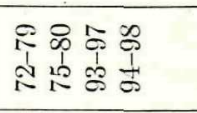 & 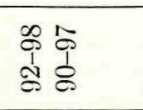 & 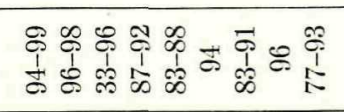 & $\begin{array}{l}\overrightarrow{0} \\
0 \\
0\end{array}$ & $\begin{array}{l}\text { Pै } \\
\text { के }\end{array}$ \\
\hline 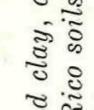 & 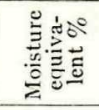 & 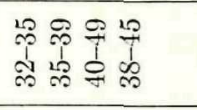 & 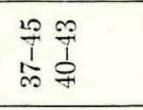 & 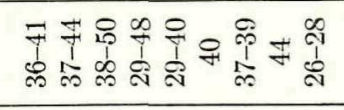 & 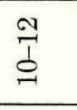 & $\begin{array}{l}\infty \\
\stackrel{1}{1} \\
\sum_{2}^{2}\end{array}$ \\
\hline 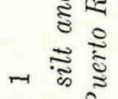 & $\frac{n}{\overline{0}} \circ^{\circ}$ & $\begin{array}{llll}\infty & 0 & 0 & 0 \\
0 & 1 & 0 \\
1 & \infty & 1 \\
-\infty & \infty & 0\end{array}$ & 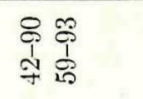 & 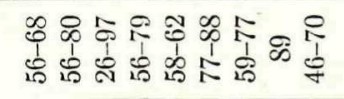 & 10 & $\underset{b}{0}$ \\
\hline 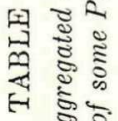 & 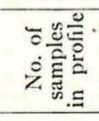 & $\infty \curvearrowleft サ+$ & $\forall \infty$ & 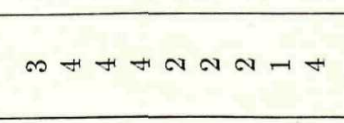 & $\infty$ & $\infty$ \\
\hline 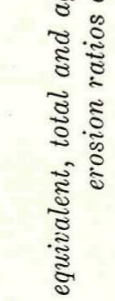 & : & 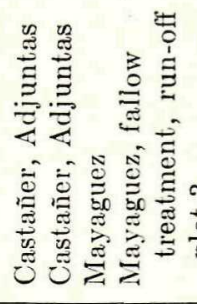 & 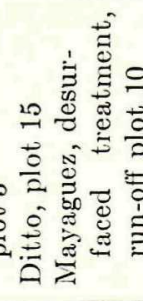 & 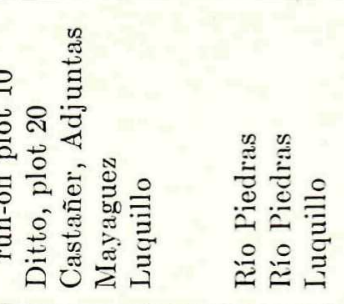 & . & 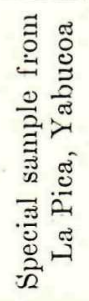 \\
\hline 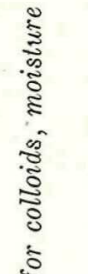 & 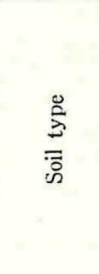 & 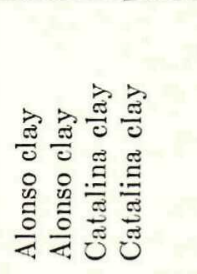 & 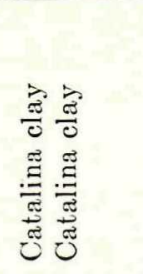 & 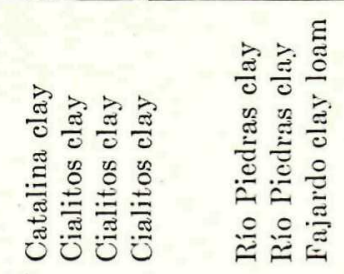 & 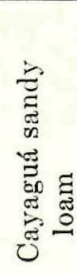 & 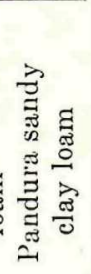 \\
\hline 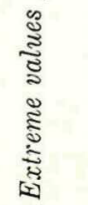 & 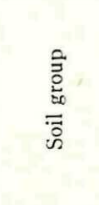 & 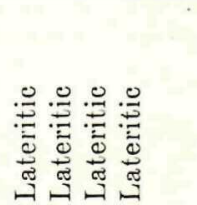 & 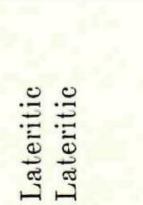 & 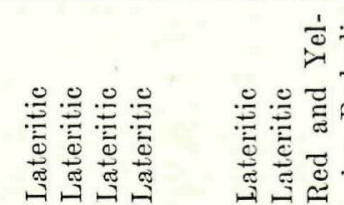 & 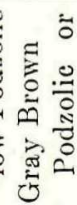 & $\begin{array}{l}\frac{2}{2} \\
0 \\
0 \\
0 \\
\frac{1}{7} \\
7 \\
7\end{array}$ \\
\hline
\end{tabular}




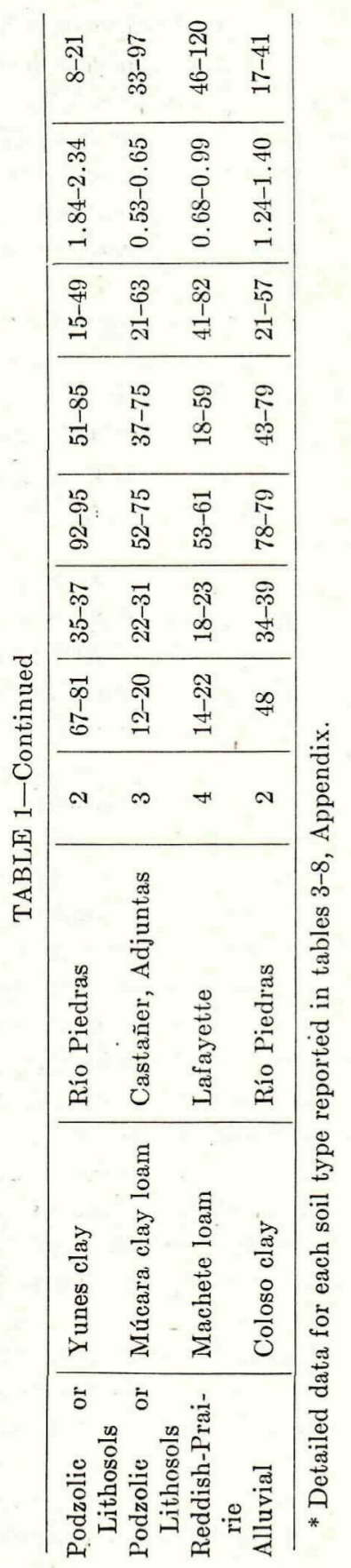


The soils are very strongly acid in all areas, except at Lafayette, where most of them are medium acid. The organic matter varies from very low to high; the lower values occurring at greater depths in the profile. The bulk density increases generally with depth. The colloids vary from 5 to $97 \%$. Lateritic soils of the Río Piedras, Catalina, Cialitos and Alonso series, have the highest colloids contents. In general, the moisture-equivalent seems to run higher in the soils that contain higher colloids; but the relationship is not linear.

The total silt and clay in the various soil profiles range from 30 to 98 percent and the silt and clay aggregated from 15 to 92 percent. Roberts (7) reports that the total silt and clay of the profile of the Nipe clay laterite in Puerto Rico varies from 71 to 86 percent and the silt and clay aggregated from 38 to 71 percent. Lutz (3) informs that the silt and clay aggregated of the non-erosive Davidson clay varies from 83 to 92 percent and of the erosive Iredell sandy clay loam from 60 to 74 percent.

The dispersion ratio is a measure of aggregation; it varies from 8 to 87 ; the lower this ratio the greater is the percentage aggregation of the silt and clay. The colloid-moisture equivalent ratio varies from 0.48 to 2.34 and the erosion ratio from 3 to 177 . No significant correlation was found between the organic matter content of the soil and either the moisture-equivalent, the dispersion ratio, the colloid-moisture equivalent ratio, or the erosion ratio. A positive significant correlation of 0.257 was found between the organic matter and the soil colloids.

Middleton (4) places tentatively non-erosive soils, as those having a dispersion ratio less than 15 , a colloid-moisture equivalent ratio higher than 1.5 , and an erosion ratio lower than 10. The Nipe clay laterite from Cuba with dispersion ratios from 5.2-6.1, colloid-moisture equivalent ratios from $2.14-2.34$, and erosion ratios from 2.2-2.9, in the upper 2 -foot layer, is the least erosive soil compared to other soils of the temperate regions reported by Middleton (4). He points out (5) that these ratios used as a criteria to estimate in advance of actual measurement of soil losses, the erosivity of a soil, leave out of consideration differences in topography, climate, vegetation, and treatment. He further pointed out (6) that slight erosion may be relatively more detrimental to fertility than more severe erosion because when the erosion is slight, the fine material predominates, and when it is large it is similar in character to the whole soil.

The data reported (table 2) for a Catalina clay profile with slopes varying from 40 to 53 percent serve as a basis to evaluate the erosiveness of this lateritic soil. The mean annual soil losses were 137 and 163 tons to the acre, in the fallow and desurfaced treatments, respectively, or 5.3 and 7.1 tons of soil per inch of run-off per acre per year, respectively. Catalina clay, a lateritic soil, with ranges of dispersion ratios of 13-20, colloid-moisture 
equivalent ratios of $0.97-2.26$, and erosion ratios of $6-14$ in its profile, loses from 5.3 to 7.1 .tons of soil per inch of run-off per acre per year, when in fallow or desurfaced. But when sugar cane was planted in this Catalina clay run-off plot, with 40 percent slope, the mean annual soil losses, as reported by. Bonnet et al (2), were reduced to 7.2 and further down to 0.67 tons to the acre, when the trash was burned or kept as a mulch, respectively, or 1.5 and 0.13 tons of soil per inch of run-off per acre per year, respectively. Farming a soil to a crop with good management of soil conservation practices reduces to a minimum the soil erosion losses. The lateritic soil, Catalina clay, when planted to sugar cane if the trash is kept as a mulch, may be classed then as a non-erosive soil.

The physical data (table 1) reveal that the red yellow podzolic Fajardo clay loam is non-erosive as the lateritic Catalina clay. The upland lateritic TABLE 2

Mean annual soil and run-off losses and range of slope, dispersion, colloid-moisture equivalent, and erosion ratios in four run-off plots of Catalina clay at Mayagüez

\begin{tabular}{c|c|c|c|c|c|c|c}
\hline Plot No. & Treatment & $\begin{array}{c}\text { Annual } \\
\text { soil losses } \\
\text { tons/acre* }\end{array}$ & $\begin{array}{c}\text { Annual } \\
\text { run-of } \\
\text { losses* } \\
\text { (inches) }\end{array}$ & Slope \% & $\begin{array}{c}\text { Dis- } \\
\text { persion } \\
\text { ratio }\end{array}$ & $\begin{array}{c}\text { Colloid- M. E. } \\
\text { ratio }\end{array}$ & $\begin{array}{c}\text { Erosion } \\
\text { ratio }\end{array}$ \\
\hline 3 and 15 & $\begin{array}{c}\text { Fallow or natural } \\
\text { vegetation }\end{array}$ & 137 & 26.0 & $40-45$ & $13-20$ & $0.97-2.26$ & $6-14$ \\
\hline $\begin{array}{c}\text { Desurfaced, 36 } \\
\text { inches of soil } \\
\text { removed }\end{array}$ & 163 & 22.9 & $46-53$ & $13-20$ & $1.37-2.26$ & $6-11$ \\
\hline
\end{tabular}

* Records from five years (1939-1943) for a mean annual rainfall of 71.5 inches, reported by B.P.I.-S.C.S. [Research Laboratory, Río Piedras.]

Alonso and Río Piedras soils and some areas of the lateritic Cialitos soils are more erosive than the Catalina clay. The level alluvial Coloso soil is also more erosive.

The gray brown podzolic or lithosols, represented by the Cayaguá sandy loam, and Pandura sandy clay loam (table 1), with ranges of dispersion ratios 27-87, colloid-moisture equivalent ratios $0.41-0.60$, and erosion ratios $67-177$, in their profiles, are highly erosive soils. The Múcara clay loam of the same group with ranges of dispersion ratios 21-63, colloid moisture equivalent ratios $0.53-0.65$, and erosion ratios $33-97$, in its profile, is also a highly erosive soil. The physical data reveal that the reddish prairie Machete loam, an alluvial soil in the semiarid area, is also an erosive soil.

There are about 343,296 acres of Múcara soils and about 116,032 acres of soils of the gray brown podzolic or lithosols derived from quartz diorite (Pandura, Cayaguá, Ciales, Tejas and Utuado series); a total of 459,328 
acres or about 21 per cent of the total area of Puerto Rico. Clean cultivated crops, specially tobacco followed by corn are grown every year in an extensive area of these uplands. No records are available of the amount of soil lost from these highly erosive soils; but it must be tremendous. To check off erosion losses it is of importance to follow soil conservation methods and to plant the cultivated areas of these soils to coffee or Molasses grass-Kudzu, Merker grass-Kudzu, or to sugar cane keeping the trash as a mulch. The steep slopes should be kept in forest or pastures.

\section{SUMMARY}

Data are presented here for $\mathrm{pH}$, organic matter, colloids, moisture equivalent, total and aggregated silt and clay, and dispersion, colloid-moisture equivalent and erosion ratios of various soils from Puerto Rico. The purpose of collecting the data was to evaluate the relative erosiveness of these soils.

An upland Catalina clay profile with dispersion ratios of $13-20$, colloidmoisture equivalent ratios of $0.97-2.26$, and erosion ratios of $6-14$, lost from 5.3 to 7.1 tons of soil per inch of run-off per acre per year, when in fallow or desurfaced, respectively. But when this soil was planted to sugar cane the losses were reduced to 1.5 and 0.13 tons of soil per inch of run-off when the trash was burned or kept as a mulch, respectively. This lateritic Catalina clay was classed as a non-erosive soil.

Three soils of the gray brown podzolic or lithosol group, represented by the Múcara, Cayaguá, and Pandura series gave higher values for dispersion and erosion ratios and lower ones for colloids-moisture equivalent ratios, in their profiles, and consequently were classed as erosive soils. Other lateritic, alluvial and reddish prairie soils were classified similarly with respect to their relative erosiveness.

\section{RESUMEN}

Se presentan aquí datos sobre $\mathrm{pH}$, materia orgánica, coloides, equivalente de humedad, limo y arcilla total y agregada, y razones de dispersión, de coloides a equivalente de humedad y de erosión, para varios suelos de Puerto Rico.

Un perfil del suelo laterítico, Catalina arcilloso, dió un valor para la razón de dispersión de 13-20, para la razón de coloide a equivalente de humedad de $0.97-2.26$, y para la razón de erosión de $6-14$, y perdió de 5.3 a 7.1 toneladas de suelo por pulgada de escorrentía por acre por año, cuando estaba en barbecho o con el subsuelo expuesto, respectivamente. Esta pérdida de suelo se redujo a 1.5 y 0.13 toneladas de suelo por pulgada de escorrentía cuando se sembró caña de azúcar y se quemó o conservó la paja, respectivamente. Este suelo se clasificó como un suelo que no es erosivo. 
Tres suelos del grupo gris pardo podsólico o litosol, representado por las series Múcara, Cayaguá y Pandura, dieron valores más altos para las razones de dispersión y de erosión y valores más bajos para la razón de coloides a equivalente de humedad, en sus perfiles respectivos. Estos suelos se clasificaron como erosivos. Otros suelos lateríticos, de aluvión, y del grupo rojo de las praderas, se clasificaron similarmente de acuerdo con su erosividad relativa.

\section{ACKNOWLEDGMENTS}

The writers wish to express their appreciation to Mr. R. Rodríguez Torrent, formerly Assistant Chemist, for planning and starting this project, taking the soil samples and performing part of the laboratory work. Thanks are also expressed to Mr. A. Rivera Brenes, formerly Assistant Chemist, for finishing the laboratory work.

Our appreciation is extended to Mr. G. L. Crawford, former officerin-charge of the Soil Conservation Service for Puerto Rico and the Virgin Islands, for providing necessary funds and facilities.

\section{LITERATURE CITED}

1. Baver, L. D., and Rhoades, H. F., Aggregate analysis as an aid in the study of soil structure relationships. Jour. Amer. Soc. Agron. 24: 920-930. 1932.

2. Bonnet, J. A., Abruña, F., and Lugo López, M. A., Trash disposal and its relation to cane yield, soil and water losses. Jour. of Agr. Univ. of P. R. 34 (3), 1950.

3. Lutz, J. F., The physico-chemical properties of soils affecting soil erosion. Mo. Agr. Exp. Sta. Res. Bul. 212. 1934.

4. Middleton, H. E., Properties of soils which influence soil erosion. U.S.D.A. Tech. Bul. 178. 1930.

5. Middleton, H. E., Slater, C. S., and Byers, H. G., Physical and chemical characteristics of the soils from the erosion experiment stations. U.S.D.A. Tech. Bul. 316. 1932.

6. Middleton, H. E., Slater, C. S., and Byers, H. G., Physical and chemical characteristics of the soils from the erosion experiment stations. Second report. U.S. D.A. Tech. Bul. 430. 1934.

7. Roberts, R. C., and party., Soil Survey of Puerto Rico. U.S.D.A. Bur. of Plant Ind. in cooperation with P. R. Univ. Agr. Exp. Sta. Series 1936, No. 8. 1942.

\section{APPENDIX}

(Tables 3-8) 


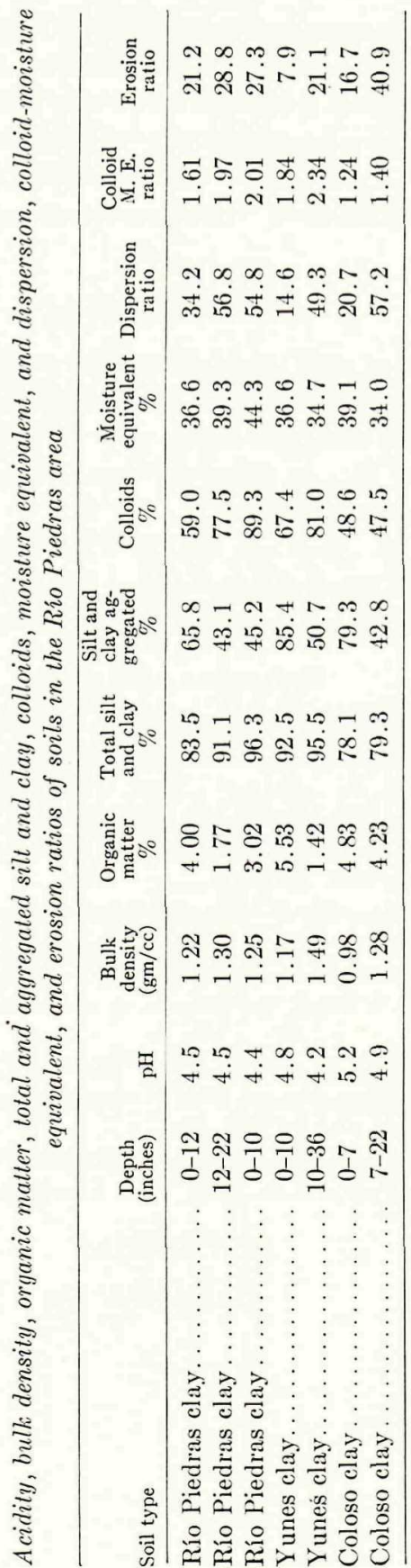




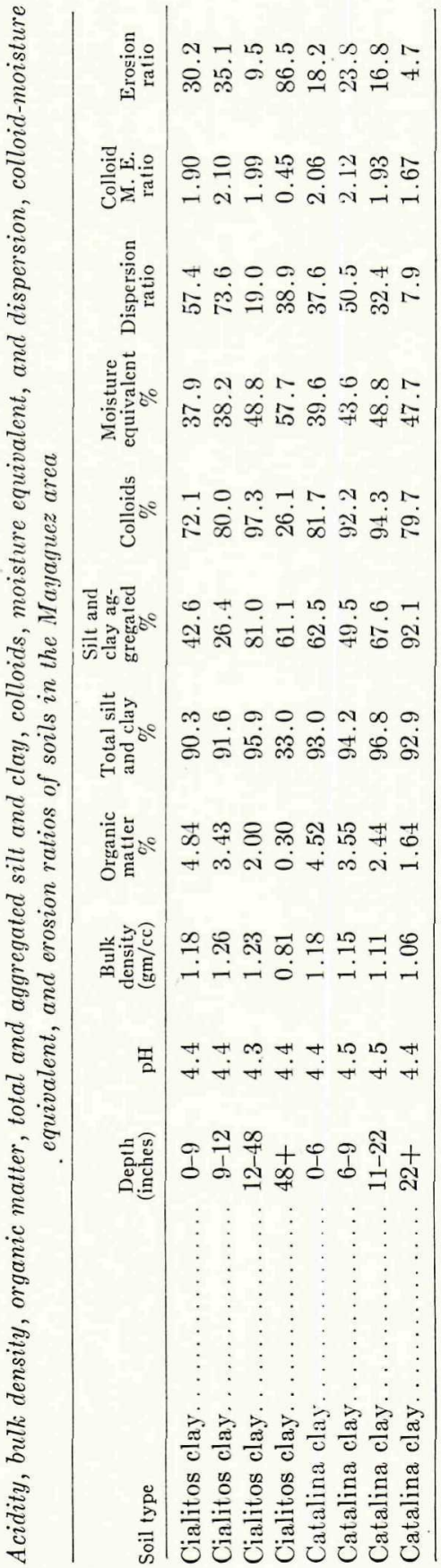


304 JOURNAL OF AGRICULTURE OF UNIVERSITY OF PEURTO RICO

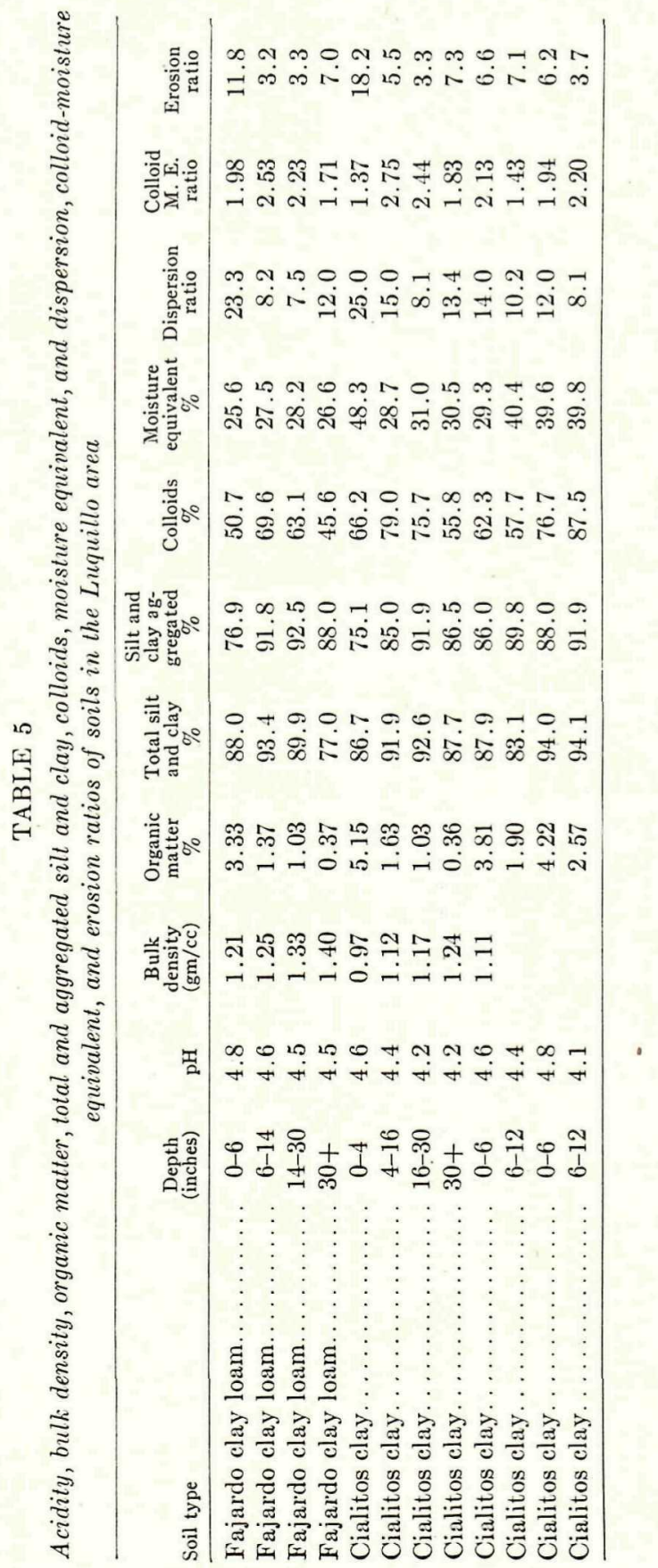




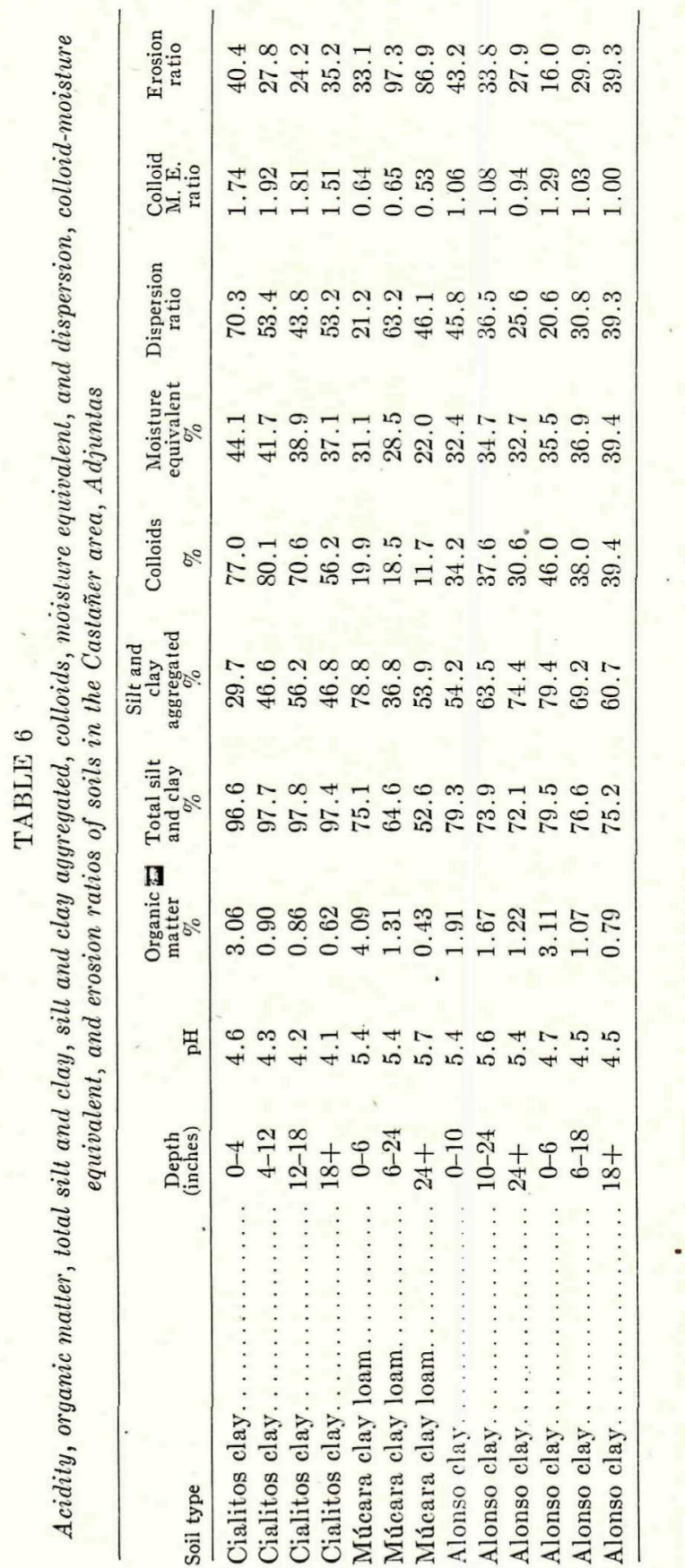


\%

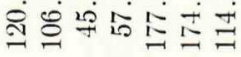

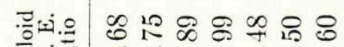
๘ उ证 0000000

$\frac{\pi}{2}$

.

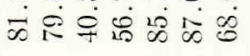
্ָ

एँ $\quad+\infty \infty-\infty$ is

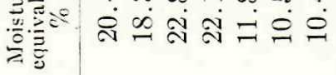

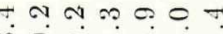

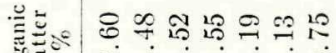
त

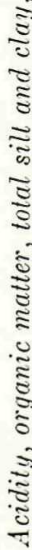

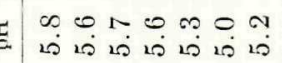




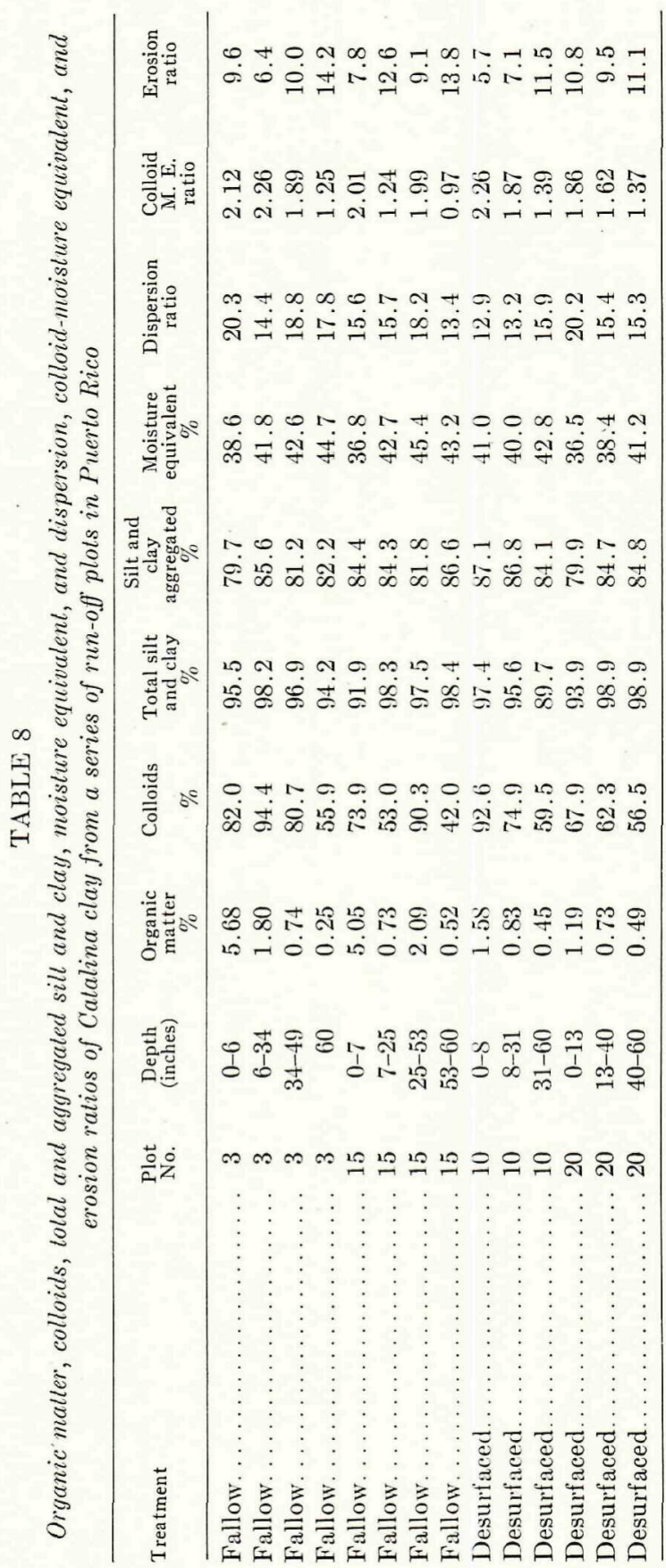

